\title{
The Syntax of Sluicing in Omani Arabic
}

\author{
Ali Algryani ${ }^{1}$ \\ ${ }^{1}$ College of Arts \& Applied Sciences, Dhofar University, Salalah, Oman \\ Correspondence: Ali Algryani, 106B, College of Arts \& Applied Sciences, Dhofar University, Oman. E-mail: \\ aalgryani@du.edu.om
}

Received: September 3, 2019 Accepted: September 30, 2019 Online Published: November 1, 2019

doi:10.5539/ijel.v9n6p337

URL: https://doi.org/10.5539/ijel.v9n6p337

\begin{abstract}
This study examines the syntax of sluicing in Omani Arabic to uncover its morpho-syntactic properties and underlying source. It also attempts to account for the apparent preposition stranding (p-stranding) effects displayed by Omani Arabic sluicing, which indicates that the language is a counterexample to the p-stranding generalisation (Merchant, 2001). The paper concludes that sluicing exists in the language and it is derived from regular wh-questions by wh-movement and TP ellipsis at PF. Furthermore, Omani Arabic displays pseudo-sluicing (i.e., an elliptical cleft wh-question), which can also be derived via wh-movement from spec-TP to spec-CP plus TP deletion at PF. Finally, the study argues that the apparent cases of sluicing under p-stranding are actually pseudo-sluicing. The drop of copular pronouns in the sluiced clause and omission of the preposition with the relative clause lead to the illusion that sluicing in Omani Arabic exhibits p-stranding effects.
\end{abstract}

Keywords: sluicing, pseudosluicing, ellipsis, wh-movement, preposition stranding

\section{Introduction}

The term 'sluicing' refers to a structure in which an isolated wh-phrase replaces and functions as an understood embedded wh-question (Gulicover \& Jackendoff, 2005). In such a construction, an entire interrogative clause is phonologically reduced to a wh-phrase, which normally has an overt correlate in the antecedent clause. Sentence (1) is an example of sluicing where the crossed-out text is the unpronounced but interpreted as a fully pronounced wh-question.

(1) John bought something, but I don't know what-i [John bought $-\mathrm{t}_{-\mathrm{i}}$ ]

This study attempts to explore the syntax of sluicing in Omani Arabic from a generative perspective in order to identify the morpho-syntactic properties of sluicing, and how such an elliptical phenomenon is manifested in the language. In addition, it aims to find out whether what appears sluicing is an instantiation of sluicing or pseudosluicing, and if sluicing, whether it can be analysed as an elliptical wh-question derived via movement plus PF deletion of the TP functioning as a complement of the displaced wh-phrase. Given that this ellipsis phenomenon has not been studied in this variety of Arabic, the study seeks to provide the first description of sluicing in Omani Arabic and propose an analysis for this elliptical structure within the generative paradigm.

The study is based on data collected from native speakers of Omani Arabic. The informants are undergraduate students at Dhofar University, who, in an interview, were asked to construct and grammatically judge sentences containing sluicing constructions. The data obtained from informants was transcribed, glossed and analysed. Based on the analysis of the data, generalisations about the language with respect to sluicing are made.

The paper is structured as follows: section 1 is an introduction to the study. It introduces the ellipsis phenomenon of sluicing and states the study issue, aims, methodology and organisation. Section 2 is concerned with the syntax of sluicing in syntactic theory. Section 3 presents sluicing and sluicing typology in Omani Arabic. It examines the internal syntax of sluicing in order to determine whether it can be analysed as sluicing or pseudo-sluicing. Section 4 discusses sluicing in preposition stranding contexts, and it puts forward an analysis for sluicing and pseudosluicing in the language. Finally, section 5 concludes the study.

\section{Sluicing in Syntactic Theory}

In syntactic theory the term 'sluicing' refers to the ellipsis of a sentential complement of an interrogative wh-phrase which replaces and functions as a complete wh-question. The structure in (2) is an example of sluicing from English, which is interpreted as a fully pronounced wh-question. I refer to the crossed-out material 
as the sluiced/elliptical clause; the XP corresponding to the wh-remnant is the correlate ('someone' in 2) and the clause containing the correlate is referred to as the antecedent clause (John met someone).

(2) John met someone, but I don't know who [John met].

Sluicing presents unanswered queries; it is an interdisciplinary topic that involves the interface of syntax, semantics and/or pragmatics. Sluicing has been accounted for by non-structural and structural approaches. Generally, there are two main approaches with respect to the syntactic structure of sluicing. The first approach is the non-structural approach which assumes no existence of syntactic structure in the ellipsis site of sluicing (Riemsdlik, 1978; Ginzburg \& Sag, 2000; Gulicover \& Jackendoff, 2005).

The second is the structural approach which argues for a structure in the elided material, and it is represented by most of the analyses (Ross, 1969; Chung, Ladusaw, \& McCloskey, 1995; Chung, 2006; Merchant, 2001, 2008, 2019; Aelbrecht, 2010; Craenenbroeck, 2010a; Leung, 2014b; Abels, 2018). However, there is disagreement as to whether or not the unpronounced material contains lexically null elements. The two dominating structural approaches are LF-Copying and PF-Deletion. The former assumes a null category filled by copying the semantic component of the antecedent clause at LF (Chung, Ladusaw, \& McCloskey, 1995; Lobeck, 1995). The latter argues for a syntactic structure within the null TP which is deleted after a wh-movement operation has taken place (Lasnik, 2007; Merchant, 2001, 2008; Aelbrecht, 2010; Craenenbroeck, 2010a; Leung, 2014b; Abels, 2018).

The ellipsis phenomenon of sluicing has been studied in several languages such as English (Merchant, 2001), Japanese (Fukaya, 2012), Spanish (Vicente, 2008), Polish (Szczegelniak, 2005), Mandarin Chinese (Adams \& Tomioka, 2012), Turkish (Ince, 2012), Libyan Arabic (Algryani, 2012), Emirati Arabic (Leung, 2014a \& b), etc. However, to the best to my knowledge, sluicing has not been investigated in Omani Arabic. Thus, the present study attempts to provide the first description of this ellipsis phenomenon in the language.

With respect to studies on sluicing in Arabic, sluicing has been studied in Libyan Arabic and Emirati Arabic. Algryani (2012) studied the syntax of sluicing in Libyan Arabic and concluded that sluicing exists in the language and that, similar to other languages, it derives from regular wh-questions via wh-movement and TP deletion. Furthermore, accounting for the apparent preposition stranding effects displayed by sluicing in the language, Algryani (2012) argues that sluices with p-stranding effects are pseudo-sluices, i.e., reduced wh-clefts, and that sluicing in Libyan Arabic does not permit p-stranding.

Another study conducted by Leung (2014b) on Emirati Arabic sluicing shows that sluicing exists in Emirati Arabic and that it is derived by wh-movement and TP deletion at PF. As for the p-stranding effects, Leung (2014a) argues that sluicing in Emirati Arabia allows p-stranding despite the fact that p-stranding is strictly prohibited under wh-movement in Emirati Arabic. To account for the violation of the preposition stranding generalization, Leung (2014a) states that the p-stranding effects in Emirati Arabic sluicing are determined at PF and therefore sluicing can rescue $\mathrm{p}$-stranding violations.

\section{Sluicing in Omani Arabic}

As a variety of Arabic, Omani Arabic (henceforth, OA) displays the ellipsis phenomenon of sluicing in both main clause and embedded clause contexts, as in (3) and (4) respectively. Similar to other languages, sluicing in OA is licensed by interrogative complementisers only. It is worth noting that sluicing constructions in embedded contexts are introduced by verbs selecting CP complements. Such verbs include know, guess, say, remember, etc. The following are examples of sluicing from Omani Arabic.
(3) A: Zayd qabəl had.
Zayd met.3Ms someone
'Zayd met someone.'
B: mi:n?
who
'Who?'
(4) šaxəs rsall-ah hadiyya lakən ma-adri mi:n

someone sent.3MS-HIM gift but NEG-know.1s who
'Someone sent him a gift, but I don't know who.' 


\subsection{Typology of Sluicing}

Merchant (2001) points out four types of sluicing constructions. These are sluices with adjuncts wh-phrases, sluices with overt correlates, sluices with implicit arguments and contrast sluices.

\subsubsection{Sluices with Adjunct Wh-Phrases}

In this type of sluicing, the remnant wh-phrase is an adjunct wh-expression and it does not have a correlate in the antecedent clause, as shown in (5).

(5)

$$
\begin{array}{lllll}
\text { Zayd } & \text { rāh, } & \text { lakən } & \text { ma-adri } & \text { mita/wein. } \\
\text { Zayd } & \text { left.3MS } & \text { but } & \text { NEG-know.1s } & \text { when/where }
\end{array}
$$

'Zayd left, but I don't know when/where.'

The adjunct remnant wh-phrases in (5) mita 'when' and wein 'where' have adverbial functions referring to time and place expressions respectively. Sluices with adjunct wh-phrases do not require a correlate in the antecedent to refer to, as shown in (5), as adjunct wh-phrases are not required by the argument structure of the verb.

\subsubsection{Sluices with Overt Correlates}

The sluiced wh-phrase in such sluices has an indefinite overt correlate in the antecedent clause. In (6), the sluiced wh-phrase mi:n 'who' refers to the indefinite overt correlate in the antecedent clause, which is had 'someone'. The syntactic category of the indefinite correlate has to be identical to that of the wh-remnant.

(6) Zaid qabəl had, lakən ma-ąraf mi:n.
Zaid met.3MS someone but

'Zaid met someone, but I don't know who.'

\subsubsection{Sluices with Implicit Arguments}

In this type of sluicing, the wh-expression has no overt correlate in the antecedent, but it corresponds to an implicit argument licensed by the argument structure of the verb. As shown in (7), the remnant wh-phrase in the sluiced clause eiš 'what' corresponds to an implicit object licensed by the verb yəqra 'read'.

(7) Fatema təqra, lakən ma-Yaraf eiš.

Fatema read.3Fs but NEG-know.1s what

'Fatema is reading, but I don't know what.'

\subsubsection{Contrast Sluices}

Contrast sluices are those sluices in which the descriptive content of the remnant wh-phrase clashes with that of its correlate in the antecedent. In (8), the wh-phrase kam bent 'how many daughters' contrasts in content with its correlate in the antecedent walad 'son'.

$\begin{array}{llccccc}\text { (8) Zayd } & \text { Gand-ah } & \text { walad, } & \text { lakən } & \text { ma-adri } & \text { kam } & \text { bent. } \\ \text { Zayd } & \text { has.3MS } & \text { son } & \text { but } & \text { NEG-know.1s } & \text { how many } & \text { daughter }\end{array}$

'Zayd has a son, but I don't know how many daughters.'

\subsection{The Underlying Source of Omani Arabic Sluicing}

Following the ellipsis approach, the ellipsis site in sluicing has a syntactic structure of a regular wh-question (Merchant, 2001\& 2006; Leung, 2014; Abels, 2018 among others). Thus, the derivation of sluicing involves movement of the wh-phrase followed by deletion of the TP at PF, as illustrated in (9). Other analyses of sluicing have been proposed, however. An alternative analysis of sluicing particularly in null subject languages is that sluicing is derived from an underlying copular clause, as in (10).

(9) John ate something, but I don't know [CP what-i [тP $\left.{ }_{-1}-t_{-i}\right]$.

(10) John ate something, but I don't know what it was.

In null subject languages such as Japanese, sluicing has been analysed as a form of elliptical wh-questions (Takahashi, 1994) and as a reduced wh-cleft (Shimoyama, 1995; Kuwabara, 1996). Merchant points out that the two possible analyses of Japanese sluicing are due to the fact that Japanese is a null subject language and that it allows the omission of copulas. Similarly, Adams and Tomioka (2012) studied Mandarin Chinese sluicing and concluded that the apparent cases of sluicing should be analysed as pseudo-sluicing. The proposed pseudo-sluicing analysis captures the language-specific morpho-syntactic properties of sluicing in Mandarin 
Chinese such as the obligatory presence of overt correlates in the antecedent clause, the presence of copulas and finally island repair effects as such an analysis does not involve movement and deletion and therefore no island violation is attested (Adams \& Tomioka, 2012)

It is worth noting that Merchant (2001) argues against a cleft (i.e., pseudo-sluicing) analysis for English sluicing. $\mathrm{He}$ argues that the syntactic behaviour of the wh-phrase in sluicing and pseudo-sluicing (i.e., wh-clefts) is distinct with respect to adjuncts, implicit arguments, prosody, aggressively non-D-linked wh-phrases, mention-all' modification, else-modification, clefted constituents and morphological case matching.

As for Omani Arabic sluicing, it can be analysed as sluicing and/or pseudo-sluicing in some contexts. Example (11), for instance, can be analysed as sluicing or pseudo-sluicing due to the presence of the copular pronoun 'hu' (he), which is used in cleft constructions. Another example is sluicing with implicit arguments, as in (12), which can have a regular or a cleft wh-question as an underlying source. Furthermore, wh-phrases in Omani Arabic are not morphologically inflected for case, as in (11), thus making it unclear whether or not the sluiced wh-phrase displays the case of its correlate in the antecedent.
(11) Zayd šaf
Zayd saw.3MS
ḥad,
lakən
ma-ąraf
mi:n (hu).

'Zayd saw someone, but I don't know who.'
(12)
$\begin{array}{lllll}\text { Zayd } & \text { yəqra, } & \text { lakən } & \text { ma-Yaraf } & \text { eiš. } \\ \text { Zayd } & \text { read.3MS } & \text { but } & \text { NEG-know.1s } & \text { what }\end{array}$

'Zayd is reading, but I don't know what.'

To find out whether cases such as (11) and (12) are instances of sluicing or pseudo-sluicing, some of the diagnostic tests proposed by Merchant (2001) will be applied to Omani Arabic data. This will determine the underlying source of sluicing and the contexts in which it occurs.

\subsection{Sluicing Defining Diagnostics}

\subsubsection{Adjuncts and Implicit Arguments}

Merchant (2001) argues that the distribution of adjuncts and implicit arguments exhibits dissimilar syntactic behaviour with respect to sluicing and clefting (pseudo-sluicing). Sluicing with adjuncts and implicit arguments is grammatical; however, sprouting implicit arguments as pivots of a reduced cleft is highly degraded. Consider the examples below.

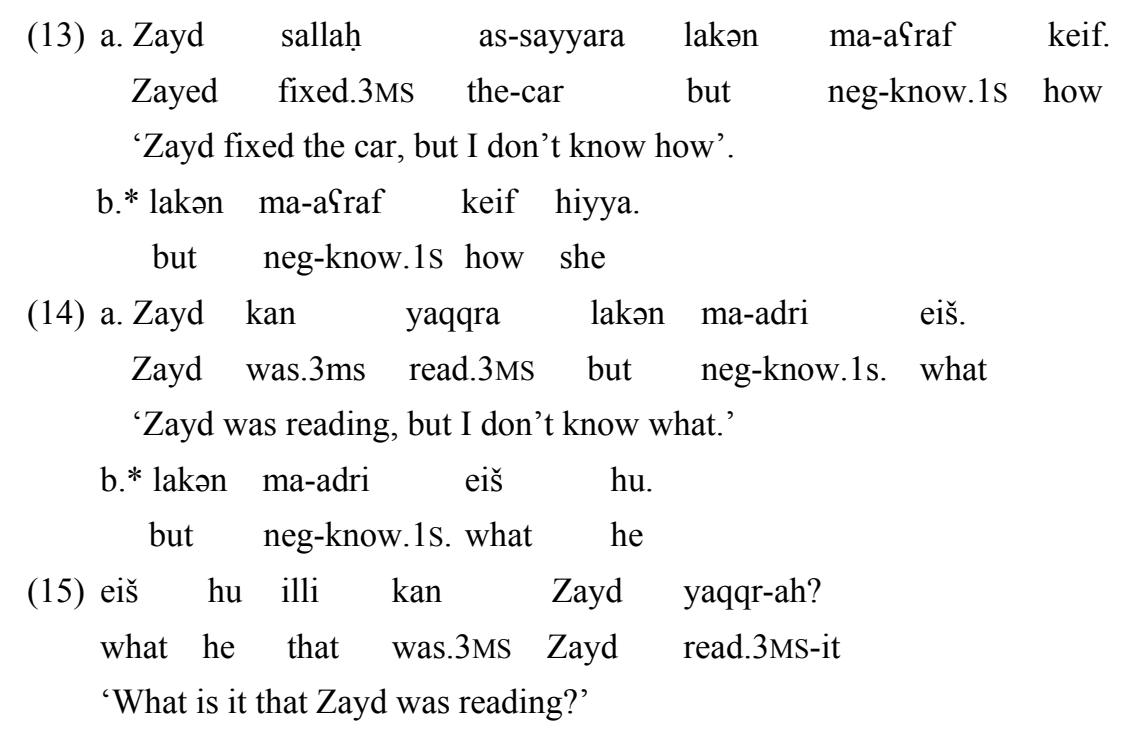

The data in (13) are cases of adjuncts and in (14) are examples of implicit arguments. Sluicing with both is grammatical; however, adjunct wh-expressions are incompatible with clefts, indicating that sluices with adjunct wh-remnants can only be sluicing. With regards to implicit arguments, sluicing is grammatical and so is full cleft wh-questions, as in (14a) and (15) respectively; however, implicit arguments with pseudo-sluicing is ungrammatical, as illustrated by the contrast in (14b). This leads to the conclusion that in implicit arguments contexts the underlying source of sluicing can be either a regular or cleft wh-question due to the availability of the copular source as an underlying source. 


\subsubsection{Prosody}

It is argued that the intonational contour associated with sluicing and pseudo-sluicing is distinct. In English sluicing, for instance, the pitch accent falls on the wh-phrase, whereas in pseudo-sluicing, the accent falls on the copula. Omani Arabic seems to pattern with English in this respect. As the data in (16b) shows, accenting 'mi:n' is unacceptable in pseudo-sluicing. The pitch accent falls on the copular pronoun.

$\begin{array}{clllll}\text { (16) a. had } & \text { rasal-uh } & \text { risala } & \text { lakən } & \text { ma-aGraf } & \text { mi:n } \\ \text { Someone } & \text { sent.3Ms-him } & \text { letter } & \text { but } & \text { neg-know.1s } & \text { who }\end{array}$

'Someone sent him a letter, but I don't know who/ who it was.'

b. *lakən ma-a@raf mi:n hu.

but neg-know.1s who he

c. lakən ma-ąraf mi:n hu.

but neg-know.1s who he

'but I don't know who it was.'

\subsubsection{Languages with Limited or No Cleft Strategy}

Some languages either lack cleft structures or have very limited clefting strategy; however, these languages exhibit sluicing. Omani Arabic has a limited clefting strategy given that adjuncts and prepositional phrases cannot be clefted; however, sluicing is commonly used in the language. In Omani Arabic, prepositional phrases cannot appear in a cleft wh-question, as in (17), but they are acceptable in both regular and elliptical wh-questions (i.e. sluicing). The ungrammaticality of (17) is ascribed to the ban on clefting prepositional phrases in the language. This confirms that sluices with prepositional wh-expressions, as in (18), are cases of genuine sluicing.

$\begin{array}{cccccc}\text { (17) *maSa } & \text { mi:n } & \text { hu } & \text { illi } & \text { rah } & \text { Zayd? } \\ \text { with } & \text { who } & \text { he } & \text { who } & \text { went.3Ms } & \text { Zayd }\end{array}$

'With whom was it that Zayd went?' (Intended reading)

(18) Zayd rah maSa had lakən ma-adri maSa mi:n.

Zayd went.3MS with someone but neg-know.1s with who

'Zayd went with someone, but I don't know with whom.'

\subsubsection{Case Matching}

Languages with rich case system seem to provide evidence against assimilating sluicing to cleft structure. In case-marked languages such as Greek, which has both sluicing and pseudosluicing, the case of the wh-phrase of a pseudo-sluice is always nominative, as in (20), whereas the case of wh-phrase in sluicing must match the case of its correlate in the antecedent clause, as in (19).

Greek

(19) I astinomia anekrine enan apo tous Kiprious prota, ala dhen ksero $\left\{{ }^{*}\right.$ pjos/pjon $\}$

the police interrogated one.ACC from the Cypriots first but not I.know who.NOM/who.ACC

'The police interrogated one of the Cypriots first, but I don't know who.'

Greek

(20) I astinomia anekrine enan apo tous Kiprious prota,

the police interrogated one.ACC from the Cypriots first

ala dhen ksero \{pjos /*pjon\} itan.

but not I.know who.NOM who.ACC it.was

'The police interrogated one of the Cypriots first, but I don't know who (it was).'

(Craenenbroeck, 2010b, p. 1717)

As for Omani Arabic, case is not marked morphologically in the language; therefore, wh-phrases in sluicing, for example in (21), are not inflected for case, which makes the distinction between sluicing and pseudo-sluicing in some contexts rather hard. 


\section{(21) Zayd zar hạ, lakən ma-aGraf mi:n. \\ Zayd visited.3MS someone but NEG-know.1s. who \\ 'Zayd visited someone, but I don't know who.'}

Table 1. Sluicing-defining diagnostics

\begin{tabular}{lll}
\hline Diagnostics & Sluicing & Pseudosluicing \\
\hline Adjuncts & $\sqrt{ }$ & $*$ \\
Implicit arguments & $\sqrt{ }$ & $\sqrt{ }$ \\
Prosody & $\sqrt{ }$ & $*$ \\
PP remnants & $\sqrt{ }$ & $*$ \\
Case-matching & - & - \\
\hline
\end{tabular}

Based on the findings of the sluicing-defining tests, it is concluded that the underlying source of sluices with adjunct wh-phrases, argument PP wh-phrases in addition to contrast sluices is a regular wh-question, thus can be derived via wh-movement plus clausal ellipsis. However, the underlying source of sluices with an overt correlate and sluices with implicit arguments can be either regular or cleft wh-questions given the fact that such sluices permit the presence of copular pronouns, indicating that a copular underlying source is available.

\section{Preposition Stranding Under Sluicing}

Merchant (2001) states that preposition stranding is permitted in sluicing only if it is permitted in non-elliptical wh-questions. Based on the behaviour of prepositions in wh-movement, Merchant (2001) states the following generalization:

A language $L$ will allow preposition stranding under sluicing if $L$ allows preposition stranding under regular wh-movement (Merchant 2001, p. 92).

It follows that $\mathrm{p}$-stranding languages allow $\mathrm{p}$-stranding in both regular wh-movement and sluicing while non-stranding languages do not permit $\mathrm{p}$-stranding in overt wh-movement or sluicing. The following are two examples from $\mathrm{p}$-stranding and non-p-stranding languages respectively:

English

(22) a. Peter spoke to someone, but I don't know (to) who(m).

b. Who did Peter speak to?

Greek

(23) a. *Pjon milise me?

who she.spoke with

b. I Anna milise me kapjon, alla dhe ksero *(me) pjon.

the Anna spoke with someone but not I.know with who

(Merchant, 2001, p. 94)

The p-stranding generalization is considered an argument in favour of deriving sluicing from wh-questions via a wh-movement operation followed by TP deletion at PF. Recent studies, however, have revealed that this generalization cannot be maintained since it apparently seems to be violated by a number of languages such as Libyan Arabic (Algryani, 2010 \& 2012), Emirati Arabic (Leung, 2014a), Spanish (Vicente, 2008), Brazilian Portuguese (Almeida \& Yoshida, 2007) and Polish (Szczegelniak, 2005).

As a non-p-stranding language, Omani Arabic is apparently another counterexample to the p-stranding generalization, as in (24). P-stranding is not permitted in regular wh-questions; however, it is possible under sluicing.
(24) Zayd rah
maSa had,
lakən
ma-ahraf
(maSa)
mi:n.
Zayd went.3MS with someone but
NEG-know.1s. (with)
who(m)
'Zayd went with someone, but I don't know (with) who(m).'

\subsection{P-Stranding in Omani Arabic Sluicing}

Omani Arabic prohibits p-stranding in non-elliptical wh-questions, yet it allows p-stranding under sluicing, as 
shown in (25) and (26) respectively. Native speakers of the language consider the prepositionless variants of the sluicing the same as the pied-piping variants. Both are consistently perceived equal and permissible. However, Omani Arabic does not seem to pattern with non-p-stranding languages. Though $\mathrm{p}$-stranding is not permitted under regular wh-movement, a preposition can be stranded in a wh-question provided that the wh-question is a resumptive wh-question, in which a resumptive pronoun referring back to the wh-remnant is attached to the preposition.

No p-stranding in regular wh-questions

$$
\begin{aligned}
& \text { (25) a. maSa mi:n rah } \quad \text { Zayd? } \\
& \text { with whom went.3MS Zayd } \\
& \text { 'With whom did Zayd go?' } \\
& \text { b. *mi:n rah Zayd maSa? } \\
& \text { whom went.3Ms Zayd with } \\
& \text { 'Who did Zayd go with?' (Intended) }
\end{aligned}
$$

P-stranding is permitted in sluicing

$\begin{array}{lllllll}\text { (26) Zayd } & \text { rah } & \text { maSa } & \text { had, } & \text { lakən } & \text { ma-aSraf } & \text { mi:n. } \\ \text { Zayd } & \text { went.3MS } & \text { with } & \text { someone } & \text { but } & \text { NEG-know.1s. } & \text { who }\end{array}$

'Zayd went with someone, but I don't know who.'

Following the ellipsis approach, (25a) is derived via movement of the wh-phrase to Spec-CP. This operation is followed by TP deletion at PF in sluicing. However, the sluice in (26) involves p-stranding. The structure is grammatical though Omani Arabic is a non-p-stranding language. This suggests that the language is another counterexample to the p-stranding generalisation. As (25b) illustrates, the sluice in (26) cannot be derived from a regular wh-question simply because the underlying source then would an ungrammatical structure. Thus, the alternative analysis which is proposed in this paper is that sluicing under p-stranding stems from a copular source and therefore should be analysed as pseudo-sluicing. This implies, which is the case, that there are two underlying sources from which sluicing can be derived, i.e., regular wh-questions and resumptive wh-questions. Since both structures are assumed to derive from wh-questions, it is worth discussing the modes of wh-question formation in Omani Arabic.

\subsection{Modes of Wh-Questioning in Omani Arabic}

There are three types of wh-questions in Omani Arabic: regular, resumptive and in-situ wh-questions. The wh-phrase in regular wh-questions appears clause-initially in both matrix and embedded clauses and is associated with an empty category marking the position of the variable bound by the wh-phrase, as in (27) and (28) respectively:
(27) eišs-i
ištara
Zayd-i?
what
bought.3MS
Zayd
'What did Zayd buy?'
(28) ma-aGraf mi:n-i ${ }^{-i} \quad$ ga ams.
neg-know.1s who came.3Ms yesterday

'I do not know who came yesterday.

Resumptive wh-questions are characterized by some salient features that distinguish them from regular wh-questions: i) the presence of the complementiser illi, ii) a resumptive pronoun filling the null category assumed to be left by the wh-phrase and iii) an optional pronominal copula appearing between the wh-phrase and illi, as in (29).
(29) mi:n-i (hu) illi Zayd zar-ah-i ?
who he that Zayd visited.3ms-him
'Who did Zayd visit?'

Resumptive wh-questions are restricted to nominal wh-expressions; phrases of adverbial function and prepositional wh-phrases are not permissible, as in (30) and (31) respectively. This has also been noted for Egyptian (Wahba, 1984; Cheng, 1997; Lassadi, 2005), Palestinian Arabic (Shlonsky, 2002), Libyan Arabic 
(Algryani, 2010 \& 2012) and Emirati Arabic (Leung, 2014b). The implication of such findings on sluicing is that sluicing with adjunct and prepositional wh-phrases cam only derive from regular wh-questions.
(30) *meta hu illi Zayd zar-na?
when he that Zayd visited.3MS-us
'When was it that Zayd visited us?'
(31) *maSa mi:n hu illi Zayd rah?
with who he that Zayd went.3Ms

'With whom was it that Zayd went?'

Finally, in-situ wh-questions do not involve movement. The wh-phrase appears in its base-generated position, as in (32). In-situ wh-questions are interpreted as echo questions.
(32) Zayd zar mi:n?
Zayd visited.3MS who
'Zayd visited who?'

\subsection{Analysis of Sluicing and Pseudo-Sluicing in Omani Arabic}

Based on the fact that sluices with adjunct and prepositional wh-remnants and those with implicit arguments are only compatible with regular wh-questions, indicating that such cases are instances of sluicing, it is argued that sluicing in Omani Arabic drives from regular wh-questions, thus can be derived by movement of the wh-phrase to a clause-initial position followed by deletion of the TP at PF.

Following Merchant (2001 \& 2006), ellipsis in sluicing is licensed by an interrogative $C$ and is triggered by a syntactic feature, the [E]llipsis feature, endowed with uninterpretable [uwh, Q] features that have to be checked in order for TP ellipsis to happen. Thus, the derivation of the sluice in (33) proceeds by movement of the wh-phrase from its clause-internal position to spec-CP. Once the wh-phrase has moved to spec-CP, the unvalued features of E get checked and as a result $\mathrm{E}$ triggers the deletion of its complement TP, leaving a mere displaced wh-phrase behind.

$\begin{array}{rllllll}\text { (33) Zayd } & \text { rah maSa } & \text { had, lakən } & \text { ma-aYraf } & \text { maSa } & \text { mi:n. } \\ \text { Zayd } & \text { went.3MS with } & \text { someone } & \text { but } & \text { NEG-know.1s. } & \text { with } & \text { whom }\end{array}$

'Zayd went with someone, but I don't know with whom.'

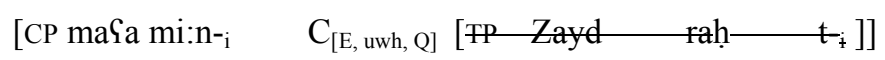

With regards to sluicing cases with apparent p-stranding effects, these derive from a copular source, thus can be considered instances of pseudo-sluicing. Building on Shlonsky's (2002) analysis of Class II wh-questions (resumptive wh-questions) in Palestinian Arabic as copular clauses consisting of a DP followed by an optional copular pronoun and a DP, I assume that pseudo-sluicing derives from a copular source via wh-movement plus TP deletion. The wh-phrase in such wh-questions moves from spec-TP to spec-CP; this movement is followed by deletion (non-pronunciation) of the TP containing the copular pronoun and the relative clause with the apparent stranded preposition, as schematized in (34).
(34) Zaid rạ
maYa
ḥad,
lakən
ma-ąraf
Zaid went.3Ms with
someone but
NEG-know.1s

'Zaid talked with someone, but I don't know who.'

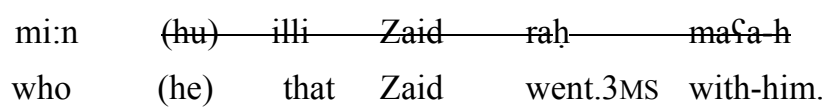

'Zayd went with someone, but I don't know who it was that Zayd went with.' (Intended)

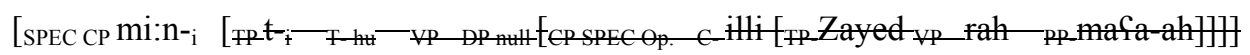

The superficial p-stranding effects under sluicing in Omani Arabic result from the omission of the pronominal copula and the relative clause containing the preposition which leads to the confusion that Omani Arabic sluicing violates the preposition stranding generalization and permits $p$-stranding.

\section{Conclusion}

This study has discussed the syntax of sluicing in Omani Arabic from a generative perspective. It concludes that 
sluicing exists in the language and that what appears as sluicing in p-stranding contexts is pseudo-sluicing. This implies that there exist two elliptical structures in the language, i.e., sluicing and pseudosluicing and both derive from two distinct underlying sources. Sluicing is derived from regular wh-questions via wh-movement and TP deletion, whereas pseudo-sluicing is derived from a copular source, i.e., cleft wh-questions via wh-movement from spec-TP to spec-CP followed by TP deletion. Finally, the p-stranding effects under sluicing result from the omission of the copular pronoun and the relative clause containing the preposition which leads to the confusion that the language allows p-stranding under sluicing.

\section{References}

Abels, K. (2018). On sluicing with apparent massive pied-piping. Natural Language \& Linguistic Theory, 1-67. https://doi.org/10.1007/s11049-018-9432-1

Adams, P. W., \& Tomioka, S. (2012). Sluicing in Mandarin Chinese: An instance of pseudo-sluicing. In J. Merchant \& A. Simpson (Eds.), Sluicing: cross-Linguistic perspectives (pp. 219-247). Oxford: OUP. https://doi.org/10.1093/acprof:oso/9780199645763.003.0010

Aelbrecht, L. (2010). The Syntactic licensing of ellipsis. Amsterdam: John Benjamins. https://doi.org/10.1075/la.149

Algryani, A. (2010). Preposition stranding in Libyan Arabic sluicing. Newcastle Working Papers in Linguistics, 16, 1-22.

Algryani, A. (2012). The syntax of ellipsis in Libyan Arabic: a generative analysis of Sluicing, VP ellipsis, stripping and negative contrast. PhD diss., Newcastle University. https://doi.org/10.5296/ijl.v5i5.4456

Cheng, L. L. (1997). On the typology of wh-questions. New York: Garland Publishing.

Chung, S. (2006). Sluicing and the lexicon: The point of no return. In R. Cover \& Y. Kim (Eds.), BLS 31 (pp. 73-91). Berkeley, CA: Department of Linguistics, University of California, Berkeley. https://doi.org/10.3765/bls.v31i1.896

Chung, S., Ladusaw, W. A., \& McCloskey, J. (1995) Sluicing and logical form. Natural Language Semantics, 3, 239-282. https://doi.org/10.1007/BF01248819

Craenenbroeck, J. v. (2010a). The syntax of ellipsis: evidence from Dutch dialects. Oxford: Oxford University Press. https://doi.org/10.1093/acprof:oso/9780195375640.001.0001

Craenenbroeck, J. v. (2010b). Invisible last resort: A note on clefts as the underlying source for sluicing. Lingua, 120, 1714-1726. https://doi.org/10.1016/j.lingua.2010.01.002

Culicover, P., \& Jackendoff, R. (2005). Simpler syntax. Oxford: Oxford University Press. https://doi.org/10.1093/acprof:oso/9780199271092.001.0001

Fukaya, T. (2012). Island-sensitivity in Japanese sluicing and some implications. In J. Merchant \& A. Simpson (Eds.), Sluicing: cross-Linguistic perspectives (pp. 219-247). Oxford: Oxford University Press. https://doi.org/10.1093/acprof:oso/9780199645763.003.0007

Ginzburg, J., \& Sag, I. A. (2000). Interrogative investigations: The form, meaning, and use of English interrogatives. Centre for the Study of Language and Information.

Ince, A. (2012). Sluicing in Turkish. In J. Merchant \& A. Simpson (Eds.), Sluicing: cross-Linguistic perspectives (pp. 248-284). Oxford: OUP. https://doi.org/10.1093/acprof:oso/9780199645763.003.0011

Kuwabara, K. (1996) Multiple wh-phrases in elliptical clauses and some aspects of clefts with multiple foci. Formal Approaches to Japanese Linguistics, 2(MITWPL 29), 97-116.

Lasnik, H. (2007). On Ellipsis: The PF approach to missing constituents. In A. Conroy, C. Jing, C. Nakao \& E. Takahashi (Eds.), Working Papers in Linguistics 15 (pp. 143-153). University of Maryland, College Park.

Lassadi, B. (2005). The syntax and semantics of optional wh-movement: the case of Egyptian Arabic. $\mathrm{PhD}$ dissertation, University of Ottawa.

Leung, T. (2014a). The preposition stranding generalization and conditions on sluicing: Evidence from Emirati Arabic. Linguistic Inquiry, 45 (2), 332-340. https://doi.org/10.1162/LING_a_00158

Leung, T. (2014b). Modes of interrogatives entail modes of sluicing: evidence from Emirati Arabic. In S. Farwaneh \& H. Ouali (Eds.), Perspectives on Arabic Linguistics XXIV-XXV (pp. 207-228). John Bejamins Publishing Company. https://doi.org/10.1075/sal.1.13leu 
Lobeck, A. (1995). Ellipsis: Functional heads, licensing, and identification. Oxford: Oxford University Press.

Merchant, J. (2001). The syntax of silence: Sluicing, islands, and the theory of ellipsis. Oxford: Oxford University Press.

Merchant, J. (2006). Sluicing. In M. Everaert \& H. van Riemsdijk (Eds.), The Blackwell Companion to Syntax (pp. 271-219). Blackwell Publishing. https://doi.org/10.1002/9780470996591.ch60

Merchant, J. (2008). Variable island repair under ellipsis. In K. Johnson (Ed.), Topics in Ellipsis (pp. 132-153). Cambridge: Cambridge University Press.

Merchant, J. (2019). Ellipsis: A survey of analytical approaches. In J. v. Craenenbroeck \& T. Temmerman (Eds.), The Oxford Handbook of Ellipsis (pp. 19-45). Oxford University Press. https://doi.org/10.1093/oxfordhb/9780198712398.013.2

Riemsdijk, H. v. (1978). A Case study in syntactic markedness: the binding nature of prepositional phrases. Dordrecht: Foris.

Rodrigues, C., Nevins, A., \& Vicente, L. (2009). Cleaving the interactions between sluicing and preposition stranding. In L. Wetzels \& J. v. d. Weijer (Eds.), Romance languages and linguistic theory 2006 (pp. 175-198). John Benjamins, Amsterdam. https://doi.org/10.1075/cilt.303.11 rod

Ross, J. R. (1969). Guess who? In R. I. Binnick, A. Davison, G. M. Green \& J. L. Morgan (Eds.), Papers from the fifth regional meeting of the Chicago linguistic society (pp. 252-286). Chicago: Chicago Linguistic Society, University of Chicago.

Shimoyama, J. (1995). On sluicing in Japanese. Ms., University of Massachusetts, Amherst.

Shlonsky, U. (2002). Constituent questions in Palestinian Arabic. In J. Ouhalla \& U. Shlonsky (Eds.), Themes in Arabic and Hebrew syntax (pp. 137-155). Dordrecht: Kluwer. https://doi.org/10.1007/978-94-010-0351-3_5

Stjepanovic', S. (2008). P-stranding under sluicing in a non-P-stranding language? Linguistic Inquiry, 39, 179-190. https://doi.org/10.1162/ling.2008.39.1.179

Szczegelniak, A. (2005). All sluiced up, but no alleviation in sight. Ms. Boston College.

Vicente, L. (2008). Syntactic isomorphism and non-isomorphism under ellipsis. Ms. UCSC.

Wahba, W. A. B. (1984). Wh-constructions in Egyptian Arabic. Ph.D dissertation, University of Illinois, Urbana.

\section{Copyrights}

Copyright for this article is retained by the author, with first publication rights granted to the journal.

This is an open-access article distributed under the terms and conditions of the Creative Commons Attribution license (http://creativecommons.org/licenses/by/4.0/). 